\title{
Phraseological units with the lexical component 'gold/golden' in English linguoculture
}

\author{
Victoria Batitskaya ${ }^{1}$, Vladimir Gurin ${ }^{1, *}$, and Elena Obletsova ${ }^{1}$ \\ ${ }^{1}$ Department of Foreign Languages and Linguodidactics, Pedagogical Institute, Irkutsk State University, 664003, Irkutsk, Russia
}

\begin{abstract}
The presented article deals with the semantic analysis of English phraseological units with the component gold/golden. As phraseological units secure cultural attitudes and stereotypes the conducted study allows one to reveal the features in the perception of gold reflected in the English language picture of the world. 62 phraseological units were sampled from various phraseological dictionaries and subjected to the semantic analysis. A set of the main meanings of the gold/golden component was identified by the generalization method that allowed one to classify the obtained proverbs into six semantic groups 'gold as power', 'gold as a cult', 'gold as a spiritual value', 'gold as a remedy', 'gold as the cause of all troubles', 'gold as devil' and reveal their evaluative characteristic. It has been found out that there is a certain duality in the perception of gold in the English language picture of the world.
\end{abstract}

\section{Introduction}

The anthropocentric approach dominating in the modern science determines the increased attention of linguists to the problem of language-culture relationships [1-4]. Linguocultural studies belong to a rapidly developing area of linguistics engaged in the investigation of these relationships, which deal with the language units of different levels with the focus on the description of phraseological composition of the language. As phraseology represents the layer of the cultural system soaked in the cultural meanings of the language system, it occupies the most significant place in linguocultural studies $[5,6]$.

In terms of cognitive linguistics, a phraseological unit is a linguistic sign that conveys a cognitive, historical, synchronic, cultural and linguistic experience of human beings $[6,7]$.

The phraseological composition of the language displays cultural values, translates the cultural content of the nation and society. Values accepted in this society influence the people as they contribute to the awareness of good and evil, virtue, and vice. In every society they serve as the milestones regulating the life of the members of each social group and the life of the society as a whole.

Phraseological units secure cultural attitudes, stereotypes, standards, archetypes and pass them on to the next generations [7-9]. It has been proved in many scientific works that phraseological units are the most complex, multiaspect objects of study. As an integral lexical unit of the language it is treated by the modern phraseology in grammatical, semantic, functional, pragmatic, sociological, and linguocultural aspects $[8$, 10-15].
Therefore, the study and analysis of phraseological units seem to be an efficient tool to widen one's knowledge on language and culture relationships. Phraseology is a mirror where the history and the centuries-old experience of people's working and spiritual activities, moral values and religious beliefs are reflected $[12,16,17]$. Phraseology represents the world of feelings, ideas and assessments inherent to people. Moreover, phraseology is an inexhaustible source of cognition of the language as a dynamically developing phenomenon [5, 7]. Researches in the field of phraseology give an insight into the history, character and culture of a nation.

The article pioneers the semantic analysis of English phraseological units with the lexical component gold/golden. The choice of the object of the analysis is determined by the fact that the named phraseological units are abundant, descriptive and expressive. The subject of the study is the semantic features of the phraseological units with the component gold/golden. Semantic analysis of the phraseological units under consideration is directed at the identification of the way gold is conceptualized in the English language picture of the world and at the specification of the set of its symbolic meanings existing in the English linguoculture.

The Merriam-Webster Dictionary defines the lexeme gold as:

1) a valuable soft yellow metal that is used to make coins, jewellery. It is a chemical element: symbol Au;

2) coins, jewellery made of gold;

3) the colour of gold;

4) (adj) made of gold

5) having the colour of gold [18].

\footnotetext{
Corresponding author: gurinvv83@rambler.ru
} 
The derivative word of the adjective gold is the word golden which is defined as having a bright yellow like gold [18].

Gold is a noble metal. Since the ancient times gold has been associated with wealth. And it is still treated as a precious metal that people aim to gaining. All that glitters reminds a man of something golden and valuable, everything that is expensive and beautiful is associated with gold. This yellow metal has never left anyone indifferent. Since old times the power of gold over people was amazing, people worshipped gold, passionately desired and cursed it.

\section{Methods}

62 phraseological units with the component 'gold/golden' have been identified by continuous sampling from various phraseological dictionaries and subjected to the semantic analysis [19-23]. The use of the component analysis allowed one to distinguish the features of the lexeme 'gold/golden' in each phraseological unit and classify the phraseological units under consideration into six semantic groups. The generalization method has been applied to identify a set of objective meanings of the 'gold/golden' component under study. The linguistic and cognitive analysis allowed one to reveal the national-cultural specifics of the perception of gold in the English language picture of the world.

\section{Results and Discussion}

\subsection{English proverbs and sayings with the lexical component 'gold/golden'}

\subsubsection{Semantic group 'gold as power'}

The semantic group 'gold as power' includes proverbs and sayings associated with power.

The idea of gold has bound all nations of the world for thousands of years. This rare metal has become a symbol of power and authority for mankind. People have always used gold as an instrument of influence. Being a special metal gold is everywhere, it is known in all parts of the world. It permeates the life of people.

The group of proverbs and sayings describing the power of gold over humankind and its fate consists of 12 phraseological units.

1. A golden hammer breaks an iron gate.

2. A golden key opens every door save that of heaven.

3. Before gold even kings take off their hats.

4. Gold goes in any gate except honor's.

5. Gold rules the world.

6 . If the walls were adamant, gold would take the town.

7. There is no lock one cannot open with a golden key.

8. A golden handshake convinces even the most skeptical judge.
9. Who has gold has ease.

10. A golden shield is of great defence.

11. Gold is the best mediator.

12. A hare may draw a lion with a golden cord.

Gold has been valued since the ancient times, the whole history of mankind can be viewed as a struggle for gold. It was used for minting coins, making beautiful jewelry, decorating exterior and interior of sacred structures or buildings designed for the rich. Gold became a symbol of kings' power, for example, the crowns were usually made of gold. Sovereigns of many countries could have armies, build cities and develop new vital spaces if they had enough gold to pay for all these. The lexemes 'ease' and 'defence' present in the structure of sayings (9) and (10) correlate with the idea of power of gold extended for protection. Moreover, the power of gold is so enormous that gold can help achieve any purpose and even enslave the whole world (this idea is manifested in the proverbs and sayings $(1,2,4,5,6$, $7)$ ). We can destroy or invade a city only by force. In the proverbs and sayings under consideration the idea of power is represented by the words 'break', 'rule', 'take', 'open', 'go'.

Phraseological units (3) and (8) demonstrate the idea of the subordinating power of gold. The proverb (12) refers to the idea that gold has the power of getting under the skin, of going in the head even to the very mighty ones: a hare fascinated a lion - the king of animals - just by waving a golden cord in front of his face.

\subsubsection{Semantic group 'gold as a cult'}

The proverbs and sayings given below present the idea of gold as a cult, which is proved by the combination of the lexeme gold and the words 'worship', 'welcome guest'. These proverbs treat gold as the purpose of human existence, as something important in itself.

1. Where my gold there my heart.

2. Worship the golden calf.

3 . Who has gold is a welcome guest.

4. Even with gold one cannot buy everything.

Gold has always been valued as money. Gold like money can take over a man. It can affect the person's mind, captivate him. The saying (2) treats gold as an obsession, as a passion for profit, wealth. A man who worships gold casts away his better spiritual part and confines oneself to material pleasures. He becomes hardhearted, his only goal is striving for more and more gold (1). Example (1) shows gold as an idol of a man who cannot survive without gold and fortune.

\subsubsection{Semantic group 'gold as a spiritual value'}

Gold fascinates people with its internal attraction as it is said that it embraces all the power of the Earth and it has its magic. People are attracted by gold like pieces of metal are attracted by a magnet. A man who worships gold withdraws his spirituality in favour of everything material and down-to-earth. This semantic group includes the proverbs and sayings demonstrating the idea of gold as something that captivates the human mind, 
thereby making a man obsessed with the lust for gold (richness), which makes a person forget about spiritual values: a good name, friendship, virtue and crime, wisdom and stupidity. The proverb (9) speaks of freedom; it cannot be bought with gold (money). You can heap a man with gold but not make him happy if he is in a golden cage. Only freedom can bring true happiness.

1. Gold and goods may be lost; a good name endures forever.

2. Gold is proved with fire, friendship in need.

3 . There is no better friend in misfortune than gold.

4. That is all well and good, but gold is better.

5. Gold glitters most when virtue shines no more.

6. You may speak with your gold and make other tongues dumb // When gold speaks you may hold your tongue.

7. A golden plate is worth nothing to me when my blood is spilled on it.

8. No man loves his fetters, be they made of gold.

9. He who expends gold properly is its master, who lays it up its keeper, who loves it a fool, who adores it an idolater; the truly wise man is he who despises it.

10. Can Wisdom be put in a silver rod, or Love in a golden bowl.

11. Gold and silver do not make men better.

12. A good heart worth gold.

13. An ass is but an ass, though laden with gold // An ass loaded with gold climbs to the top of the castle.

14. A golden bit makes none the better horse.

Sometimes very rich people (rolling in money or walking in golden slippers) forget about the vital values. Sometimes people make many friends but only one or two out of a hundred are true friends since friendship cannot be bought for money. Friendship is as precious as gold. But people tend to confuse the preciousness of gold and spiritual values. Gold and everything material can disappear at any moment, but a true friend will never leave you in trouble but always come to the rescue (2).

People who have a lot of gold, but are not its slaves are easy going and helpful, supporting others they do not become poorer, on the contrary, they become richer both spiritually and materially. Quite the opposite idea is represented in the proverb (12).

Sometimes gold can make a man callous, greedy and cunning. And one day such people find themselves to be completely alone in this world. Only money and gold are their best friends (examples $(4,6,7)$ ).

People are not always content with what they have. The nature of human beings makes them always long for something, they always want more. The flood of money (gold) makes a man stop appreciating what he has (5). On the other side people do value virtues more than gold $(8,10,13)$.

Sayings $(13,14)$ refer to the idea that gold cannot make anyone a better person, virtue cannot be bought for gold.

\subsubsection{Semantic group 'gold as a remedy'}

The semantic group 'gold as a remedy' includes sayings representing the idea of gold as an instrument to achieve a healthy state. It is enough to have gold to pay for one's treatment, it is enough to recover. Nowadays people pay money to get rid of a malevolent disease. Gold may be consolation for a human being, it can serve as balm, a medicine for the soul, a good doctor who can cure one of all ailments. These meanings are conveyed by the nouns 'doctor' and 'balm'.

1. Gold is a good doctor.

2. Gold is the balm to a wounded spirit.

3. A gold ring does not cure a felon.

\subsubsection{Semantic group 'gold as the cause of all troubles'}

The following proverbs and sayings were attributed to the semantic group «gold as the cause of all troubles» as they demonstrate the idea of gold as an evil and the cause of woes and misery in a man's life. This is proved by the combinability of the lexeme gold with the words beget hate, debate, separate, create war, kill, fear, sorrow, danger, grief.

1. Gold begets in brethren hate, Gold in families debate, Gold does friendship separate, Gold does civil wars create.

2. Golden roofs break men's rest.

3. He who has gold has fear, who has none has sorrow.

4. It is not all gold that glitters.

5. Much gold, much care.

6. Golden dreams make men awake hungry.

7. When we have gold we are in fear, when we have none we are in danger.

8. A golden dart kills where it pleases.

9. Gold when present causes fear, when absent grief.

10. Kill the goose that lays the golden eggs.

Throughout the human history gold has influenced mankind, it united and separated people, brought great joy and much grief. Gold was the cause of intrigues and wars (1) and from year to year it only strengthened its position.

Greedy for gain people often lose everything they have through their craving for fortune. Seeking to get rich at once they go off the deep end and as a result waste a lot (10).

Rich people are doomed to live in fear and danger. A lot of gold causes a lot of worries (5) since there are a lot of those willing to take possession of somebody else's property. When people possess gold they are afraid of losing it. They fear crisis, bankruptcy. People who have wasted their wealth fall into sadness and cannot go on (examples 3, 7, and 9).

\subsubsection{Semantic group 'gold as devil'}

The given proverbs and sayings below are attributed to the named semantic group as having negative connotations and including lexemes devil, devil's 
fishhook, unseen tyrant, snare of the soul used as metaphors of gold.

1. Where there is gold, there the devil dwells.

2. Gold is the devil's fishhook.

3 . Gold is an unseen tyrant.

4. Gold is the snare of the soul.

Wealth can seize a man, his thoughts, mind, body. Having acquired the taste of gold and its might, one can not stop (2). The history knows the periods of gold mining, of so-called 'golden rush' when people went mad because of gold. People were willing to do anything for gold, even to make a deal with the devil himself (1, $2,3)$, not able to escape a man is trapped (4).

Below there are proverbs and sayings, which were not attributed to the distinguished semantic groups.

1. Streets are paved with gold.

The proverb speaks about the place where money can be earned.

2. A head of oak, a heart of gold.

Unlike Russian saying 'golden heart', which is used when we refer to a kindhearted person this very proverb describes a hard person with the heart of stone.

3. Man must govern not serve gold.

Gold can enslave and submit a person. The proverb refers to the idea that a man must master gold, not gold should master a man.

4. The purest gold is the most ductile.

The saying refers to the idea that pure gold is easier to process than a fake. The same could also be said also about people. A man of integrity, not afraid to open his heart to the others is more attractive to people than those used to hiding their true self.

5. Try your skill in gilt first and then in gold.

The proverb refers to the idea that before starting something serious you need some preparation and training in order not to spoil something precious (like gold).

\subsection{English idioms with the lexical component 'gold/golden'}

\subsubsection{Semantic group 'gold as good luck'}

This semantic group contains idiomatic expressions with the positive connotation. The idiom number (1) expresses luck, the praseological unit (2) correlates with the idiom 'hit the jackpot'. In other words, gold is considered as the source of well-being, happiness, satisfaction in something.

1. Golden opportunity.

2. Strike gold.

"After a rather dissolute youth and having been disowned by his father, John Caldigate sets sail for Australia with his friend Dick Shand hoping to make his fortune in the goldfields in New South Wales. On the voyage, he meets Euphemia Smith and they conduct an indiscreet affair aboard. After various problems, Caldigate literally strikes gold and returns to Sydney where he meets Euphemia again and they settle, living as man and wife" [24].
In this example the idiom, literally, has the meaning 'hit the jackpot'. Anthony Trolope became lucky, having experienced a lot of disappointments in his life: 'Caldigate literally strikes gold and returns to Sydney where he meets Euphemia again and they settle, living as man and wife'.

\subsubsection{Semantic group 'gold as trickery'}

The idioms with the component 'gold' reflect the connection between the concept of gold and the concepts of deception and lie.

1. Fool's gold / gold leaf.

2. Sell somebody a gold brick.

The idiom (1) has a similar meaning with the saying 'All is not gold that glitters'. It translates the notion of fake, of a worthless piece of something that resembles real gold. People can deceive others for mercenary purposes. To make more money they go on to cheat. It is nothing more than 'to breed a fool for money' as described in the idiom (2).

\subsubsection{Semantic group 'gold as a good characteristic of a person'}

The idioms included in this semantic group reveal good qualities of a human-being.

1. As good as gold.

2. Good as gold.

3. A heart of gold.

4. Worth its weight in gold.

The idioms 'as good as gold' and 'worth its weight in gold' have the meaning 'a very valuable, very important, precious feature', characteristic for a man. [24].

She had lived in the country and was as good as gold

My dear, beauty is only skin deep, and common sense is worth its weight in gold [24].

The proverb (1) is a simile presenting a girl as a very good person - as good as gold. This quality is assessed as a very valuable one. The example (2) presents young girl's beauty as a subject of sale, moreover as a very valuable one.

A woman with a heart of gold

I heard her called before I knew

How noble was that heart and true,

How full of tenderness untold [24].

The idiom 'the heart of gold' used to describe a person, translates the meaning 'sincere and kind-hearted person, eager to help others'.

\subsubsection{Semantic group 'gold as a store of something'}

The idioms given below treat gold as a plentiful characteristic of something, in particular the idiom (1) indicates the meaning of a particular large amount of valuable resources (=information). The idiom (2) refers to the idea of a particular large amount of money.

1. Gold mine of information.

2. A pot of gold/ a crock of gold. 


\section{Conclusion}

The analysis of the phraseological units with the component 'gold/golden' allowed one to identify the national and cultural features in the perception of gold in the English linguistic culture.

The proverbs and sayings with the component under study were divided into six semantic groups: 'gold as power', 'gold as a cult', 'gold as a spiritual value', 'gold as a remedy', 'gold as the cause of all troubles', 'gold as devil.' The most numerous groups are 'gold as power' (includes 12 proverbs and sayings) and 'gold as a spiritual value' (includes 14 proverbs and sayings). Demonstrating the opposite meanings, these groups indicate a certain duality in the perception of gold, which is reflected in the English language picture of the world. However, such a duality in the perception of gold is also present in other national language pictures of the world (cf. Russian Золото добываем, себе могилу копаем = transl. Mining gold we dig our grave. Через золото слезы льются $=$ transl. Gold is the cause of tears. Если золото всплыло - правда утонет $=$ transl. If gold has surfaced, the truth will drown. Богатство - грязь, ум золото $=$ transl. Wealth is dirt, mind is gold. German Reden ist Silber, Schweigen ist Gold= transl. The word is silver, silence is gold).

The idioms with the component 'gold/golden' were classified into 4 semantic groups: 'gold as good luck', 'gold as trickery', 'gold as a good characteristic of a person', 'gold as a store of something'. Unlike the dual positive and negative meanings presented by the proverbs and sayings with the component 'gold/golden', the idioms with the component 'gold/golden' demonstrate only positive meanings.

The conducted analysis of the proverbs and sayings with the component 'gold/golden' suggests that, on the one hand, the delivered meanings of the component under study are quite diverse, on the other hand, evaluative positive and negative meanings predominate. Gold is used as a certain measure of the realities of human life. For example, in the group with the semantic component 'gold as power' the availability of power is assessed both positively and negatively, since the pursuit of power, on the one hand, stimulates progress, but on the other hand, can destroy a person. The analysis of the identified subgroups has allowed one to reveal the components 'gold as a virtue', and 'gold as evil', 'gold as a means of creation' and 'gold as a means of destruction' (in the first place of the human soul), 'gold as a tool of liberation' and as a 'means of enslavement', 'gold as a poison' and 'gold as a remedy'. Apart from the binary meanings there is the meaning of 'gold as a mediator in something'. No matter what component of meaning is actualized in a phraseological unit, gold is always used as a certain standard or equivalent, a measure of actions of a man and events of human life.

\section{References}

1. J. Wassmann, A. Bender, Anthropology, International encyclopedia of the social \& behavioral sciences, 16-22 (2015)

2. M. Danesi, Anthropology, International encyclopedia of the social \& behavioral sciences, 169-175 (2015)

3. H.E. Manelis Klein, Anthropological linguistics: overview, Encyclopedia of language \& linguistics, 296-304 (2006)

4. W.O. Beeman, Philosophy of linguistics, Linguistics and anthropology, 531-551 (2012)

5. J. McAlpine, J. Myles, System, Capturing phraseology an online dictionary for advanced users of English as a second language: a response to user needs 31, 71-84 (2003)

6. N. Riemer, Language and communication, Cognitive linguistics and the public mind: idealist doctrines, materialist histories 64, 38-52 (2019)

7. I.V. Zykova, Perception of verbal communication reflected in Russian and English phraseology: towards a new theory of Phraseologism-formation, Procedia - social and behavioral sciences 236, 139145 (2016)

8. R. Taukebaeva, Zh. Isaeva, B. Ospanova, Sh. Karsybekova, A. Ermekbaeva, A. Pakizat, Linguistic Analyze of Characters in the Proverbs and Sayings Procedia, Procedia - Social and Behavioral Sciences 143, 634-637 (2014)

9. T. Sela, M. Panzer, M. Lavidor, Divergent and covergent hemispheric processes in idiom comprehension: the role of idioms predictability, Journal of neurolinguistics 44, 134-146 (2017)

10. L. Williams, Ch. Bannister, M. Arribas-Ayllon, A. Preece, I. Spasić, The role of idioms in sentiment analyses, Expert system with applications 42, 7375 7385 (2015)

11. Z. Fotovatnia, M. Guodarzi, Idioms comprehension in English as a foreign language: analyzability in focus, Procedia - social and behavioral sciences 98, 499-503 (2014)

12. M.T. Espinal, J. Mateu, On classes of idioms and their interpretation, Journal of pragmatics 42, 1397 1411 (2010)

13. J. Ayto, Idioms, Encyclopedia of language \& linguistics, 518-521 (2006)

14. K. Syzdykov, Contrastive studies on proverbs, Procedia - social and behavioral sciences 136, 318321 (2014)

15. R. Moon, Corpus approaches to idiom, Encyclopedia of language \& linguistics, 230-234 (2006)

16. V. Boulinger, Y. Shtyrov, F. Pulvermüller, When do you grasp the idea? MEG evidence for instantaneous idiom understanding, Neurolmage 59, 7375-7385 (2012) 
17. J. Owens, The lexical nature of idioms, Language sciences 57, 49-69 (2016)

18. M. Webster, Merriam Webster Dictionary, URL: http://www.merriam-webster.com/dictionary/ (date of access: 20.01.19).

19. W. Mieder, Proverbs: A handbook (Greenwood Press, London, 2004)

20. M.H. Manser, The Facts on File Dictionary of Proverbs (Checkmark Books, London, 2007)
21. J. Speake, The Oxford Dictionary of Proverbs (Oxford University Press, Oxford, 2015)

22. R.A. Spears, Dictionary of American Idioms and Phrasal Verbs (McGraw-Hill, New York, 2005)

23. D. Dobrovol'skij, Idiom dictionaries, Encyclopedia of language \& linguistics, 514-518 (2006)

24. British National Corpus, URL: https:/www.englishcorpora.org/bnc/ (date of access: 28.01.19). 